\title{
Verification of bright spots in the presence of thin beds by AVO and spectral analysis in Miocene sediments of Carpathian Foredeep
}

\author{
K. Cichostępski ${ }^{1}$ (D) A. Kwietniak ${ }^{1}$ (D) J. $\operatorname{Dec}^{1}$ (D)
}

Received: 7 May 2019 / Accepted: 4 July 2019 / Published online: 12 July 2019

(C) The Author(s) 2019

\begin{abstract}
Twin structural traps that lie within the Miocene strata of the Carpathian Foredeep that are localized above Cierpisz and Mrowla-Bratkowice highs exhibit identical bright-spot seismic anomalies, but only those associated with the Cierpisz high are profitable gas reservoirs. Bright spots can be a result of weak gas or water saturation, but also seismic interference known as tuning effect. For these reasons, it is crucial to differentiate between seismic anomalies. In this article, we present the possibilities of verification of seismic anomalies that occur within the siliciclastic Miocene sediments of the Carpathian Foredeep with the application of AVO analysis and spectral decomposition. AVO methodology enabled to limit the number of anomalies that are present in the post-stack seismic data. These anomalies, however, may also be a result of tuning which is common for the heterolithic sequences in the Miocene sediments of the Carpathian Foredeep. For classification of anomalies in the view of the above, spectral decomposition based on the Basis Pursuit algorithm was applied. Spectral decomposition enabled to divide AVO anomalies in those that are the result of gas saturation and the tuning effect. Gas-saturated zones are characterized by higher spectral amplitudes of the lower frequency range, whereas tuning effect yields higher spectral amplitudes for the higher frequency content. This relation is visible for the data set and enables qualitative differentiation for the set of seismic anomalies.
\end{abstract}

Keywords AVO analysis · Spectral decomposition · Thin beds $\cdot$ Miocene sediments · Carpathian Foredeep

\section{Introduction}

Natural gas accumulations within the Carpathian Foredeep are located mostly in small structural-stratigraphic traps that are present in its whole depth profile (Myśliwiec et al. 2006 and references therein). Interpretation of such objects is difficult due to their small sizes, finely layered inner structures and the fact that the Miocene sediments that fill the Foredeep exhibit strong facial changes in all directions. These factors result in strong horizontal and lateral variations of physical parameters of both reservoir and cap rock.

Paper was presented at the CAGG 2019 Conference 'Challenges in Applied Geology and Geophysics' organized at the AGH University of Science and Technology, Krakow, Poland, 10-13 September 2019.

K. Cichostępski

kcichy@agh.edu.pl

1 Faculty of Geology, Geophysics and Environmental Protection, AGH-UST University of Science and Technology, Kraków, Poland
Many reservoirs in the Miocene sediments of the Carpathian Foredeep are within finely layered (up to $5 \mathrm{~cm}$ ) intervals of loosely consolidated sandstones. These kinds of sediments are built of thin layers of changing sandstone-mudstone, which are known as heterolithic sequences (Reineck and Wunderlich 1968). In favourable structural conditions, such an interval can accumulate hydrocarbons. Interestingly, in such a case thick sandstones within heterolithic sequences usually have only insignificant or almost no gas saturation. In the Miocene basin, gas derives nearly totally from the microbial reduction of carbon dioxide generated by breakdown of type III (humic) kerogen (Kotarba 1998; Kotarba et al. 2005). The presence of the methane within the heterolithic sequences of low porosity and permeability suggests that the source rock is also a reservoir rock. Hence, such gas accumulations can be understood as reservoirs that exist at the border between conventional and unconventional targets (Paszkowski et al. 2009).

The focal method for reservoir characterization is an analysis of direct hydrocarbon indicators (DHI). Gas accumulations within the Carpathian Foredeep exhibit strong 
negative anomaly of a bright spot type. Such anomalies, unfortunately, are very sensitive to the presence of any gas saturation (Biot 1956; Bała and Cichy 2007), which often causes seismically visible bright-spot anomalies to be nonperspective, which have resulted in several exploration failures (e.g. Allen et al. 1993; Myśliwiec 2004a, b). Many anomalies have completely different origins, for example, caused by lithofacial changes, thin bedding or uneven compaction in the Miocene sediments. For this reason, it is crucial to calibrate such an anomaly by other seismic tools, such as AVO analysis (AVO-Amplitude Versus Offset) or spectral decomposition. AVO analysis helps to classify anomalies more precisely, whereas spectral decomposition enables qualitatively to describe tuning effect (Kwietniak 2016).

Application of the frequency analysis for hydrocarbon exploration is widely described (Partyka et al. 1999; Li and Zheng 2008; Shixin et al. 2011; Ahmad et al. 2017) and applied by many authors. It is agreed that gas saturation is the main reason to generate frequency anomalies (e.g. Korneev et al. 2004). Low-frequency shadow, that is often used in such scenarios, exists but its strength and frequency drop, in reality, are very low (Barnes 1991). Nevertheless, practice shows that frequency analysis can be of some use as a DHI factor. The focal problem with the application of frequency analysis is that seismic data from a given area are never uniformly processed and that the frequency characteristics vary from one seismic survey to the other. There exists an endless list of reasons for that, for example acquisition parameters, type of source, source signatures, processing steps, etc. In reality, it is rarely possible to cover the study area with unbiased seismic data that are needed for frequency analysis. For these reasons, diagnostic frequency anomalies can have a very different origin. This is also the case in the Carpathian Foredeep-seismic data cover the majority of the basin, but these data are of very different qualities. The contractors changed, processing path and methodology have developed, and the data cannot be unified and treated with the same fidelity. For that, it is crucial to treat the frequency analysis quantitatively, rather than to search for low-frequency anomalies of a given value. Our approach is to define regions of higher-than-average and lower-than-average frequency anomalies within each separate data set. The frequency analysis applied uses basis pursuit spectral decomposition technique that enables the analysis of amplitude and phase behaviour for a given frequency range.

The described methods and implementations applied mostly for model data (Chopra and Castagna 2014 and references therein). For synthetic models, AVO analysis and spectral decomposition give unique solutions. For real data examples, results are not that ubiquitous and other effects can be observed. For these reasons, we perform the analysis on real data examples, trying to evaluate the quality of their performance.
The article aims to a present scenario, where in similar structural conditions heterolithic sequences generate DHI anomalies but not all of them exhibiting anomalies are gasbearings traps. Such an example is the Cierpisz and MrowlaBratkowice zones. For similarly elevated zones of the similar heterolithic sequences, at the distance of less than $8 \mathrm{~km}$ one exhibits commercial gas accumulation (Cierpisz reservoir, see Syrek-Moryc 2007) and the other gives only weak, noncommercial gas flows.

\section{Study area and geological setting}

The area of study is situated in the southern part of the Carpathian Foredeep, about $8 \mathrm{~km}$ away from the frontal Carpathian thrust edge (Fig. 1a). The Carpathian Foredeep contains the youngest and largely undeformed siliciclastic fill that resulted from northward thrusting of the Carpathian accretionary prism (Oszczypko 2006). The Miocene sediments are represented by finely layered mudstone-sandstone sequences. These layers manifest strong facial changes, which altogether with the wedge-like structural characteristics is beneficial for hydrocarbon accumulations (Myśliwiec et al. 2006). In the area, the Miocene sediments are of substantial thickness, reaching up to $2950 \mathrm{~m}$. In the bed of the Miocene sediments, there exist two NW-trending bedrock elevations: the Cierpisz and Mrowla highs that are separated by the paleovalleys that increase their depths in the southeastern direction up to $600 \mathrm{~m}$ (Fig. 1b). The cores of the heights underwent rotation and are highly deformed by the faults of the major NW-trending. Some of the faults that are associated with the bed of the basin are continuing in the Miocene sediments, which suggest their active character at the beginning of the Miocene sedimentation. The Cierpisz high is built by the series of Neoproterozoic anchimetamorphic sedimentary rocks succeeded by the siliciclastic and carbonate sediments of Carboniferous and Lower-Middle Triassic, siliciclastic sediments of Middle Jurassic and carbonate complex of Upper Jurassic. The Mrowla high is built by the Precambrian rocks in its core succeeded by weakly deformed Devonian-Carboniferous interval.

On the basis of the seismic record calibrated against well logs (Fig. 2), the Miocene succession within the study area can be divided into three main stratal packages: (1) situated between pre-Miocene basement and M1 horizon, bottom-most basal package, dominated by muddy lithologies and generally flat sub-parallel reflections of conspicuous lateral continuity and generally low amplitudes; (2) situated between M1 and M3 horizons, sand-rich, heterolithic middle package which is typified by high-amplitude reflections varying in geometry between flat-parallel and locally mounded; (3) situated above the M3 horizon, uppermost package which is dominated by mudstones and exhibits 


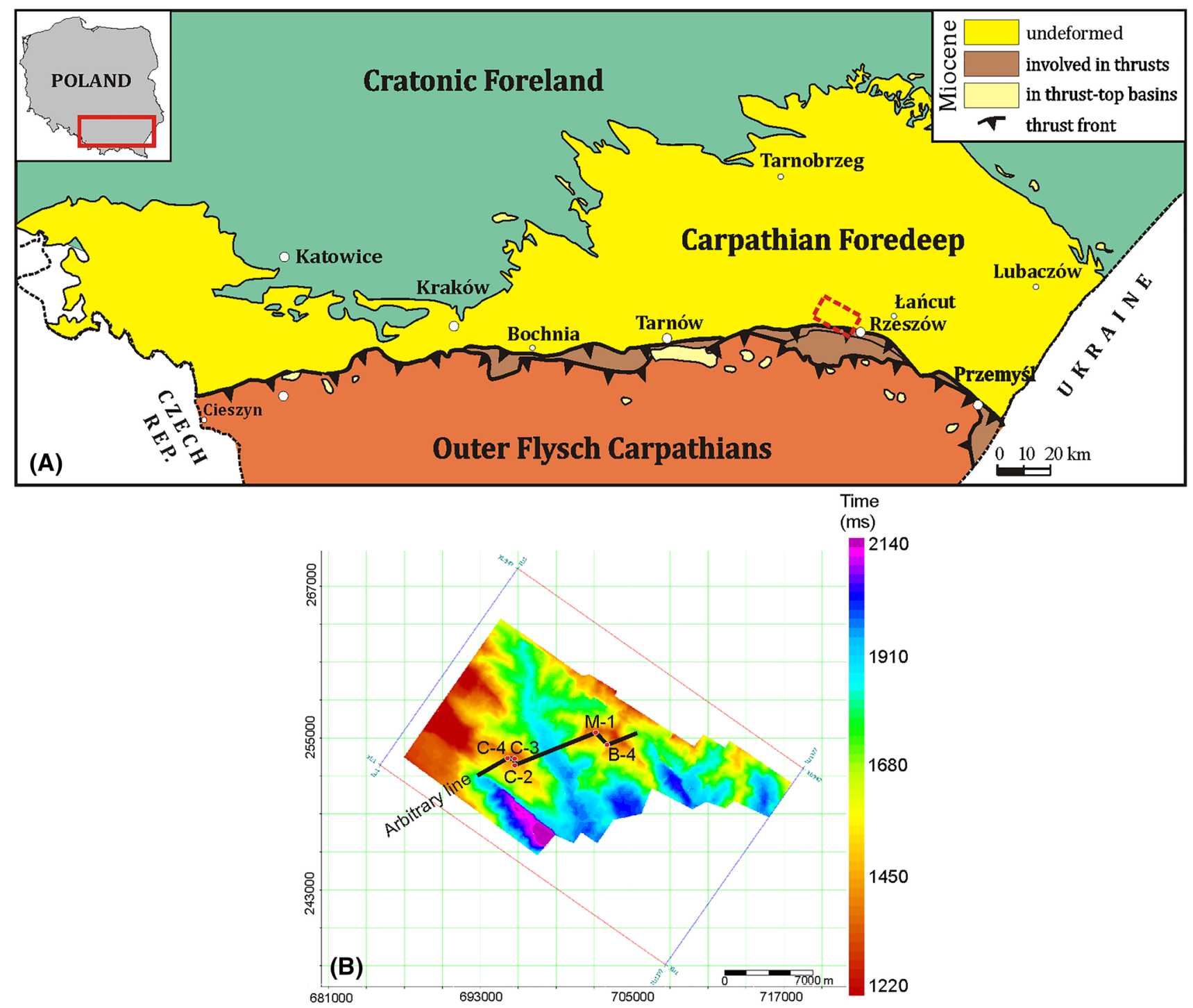

Fig. 1 Study area: a location of the study area (dashed rectangle) in the Polish part of Carpathian Foredeep; b time map of the pre-Miocene basement, showing the location of the arbitrary seismic line

intermediate to locally high-amplitude reflections arranged in large-scale oblique sets.

\section{Data set and methodology}

\section{Seismic survey}

Input data for this study come from the 3D-volume 'Trzciana-Cierpisz-Zaczernie', which was realized in 2006 by Geofizyka Kraków SA for Polish Oil and Gas Company (PGNiG). The volume covers the area of $324 \mathrm{~km}^{2}$ (see Fig. 1b). The bin size was $20 \times 20 \mathrm{~m}$ with offsets ranging up to $3 \mathrm{~km}$, which gives the average fold of 42 . Seismic sweep signal was generated with the length of $14 \mathrm{~s}$ and with bandwidth 8-100 Hz. Such parameters resulted in the average frequency of $46 \mathrm{~Hz}$ in the Miocene strata. The data set had a sampling rate of $2 \mathrm{~ms}$. The processing scheme included trace edition, spherical divergence correction, coherent noise removal, first break mute, surface consistent amplitude scaling and deconvolution, static correction, NMO correction, DMO correction, spectral whitening, CMP sort, stack, post-stack signal enchantment, FX migration (Cichostępski 2016). The data were processed with relative amplitude preservation; (Cichostępski et al. 2019a, b). In general, these data have a record length of $4 \mathrm{~s}$ two-way time (TWT) and provide good-quality imaging down to the Palaeozoic levels, except the topmost $0.35 \mathrm{~s}$. 


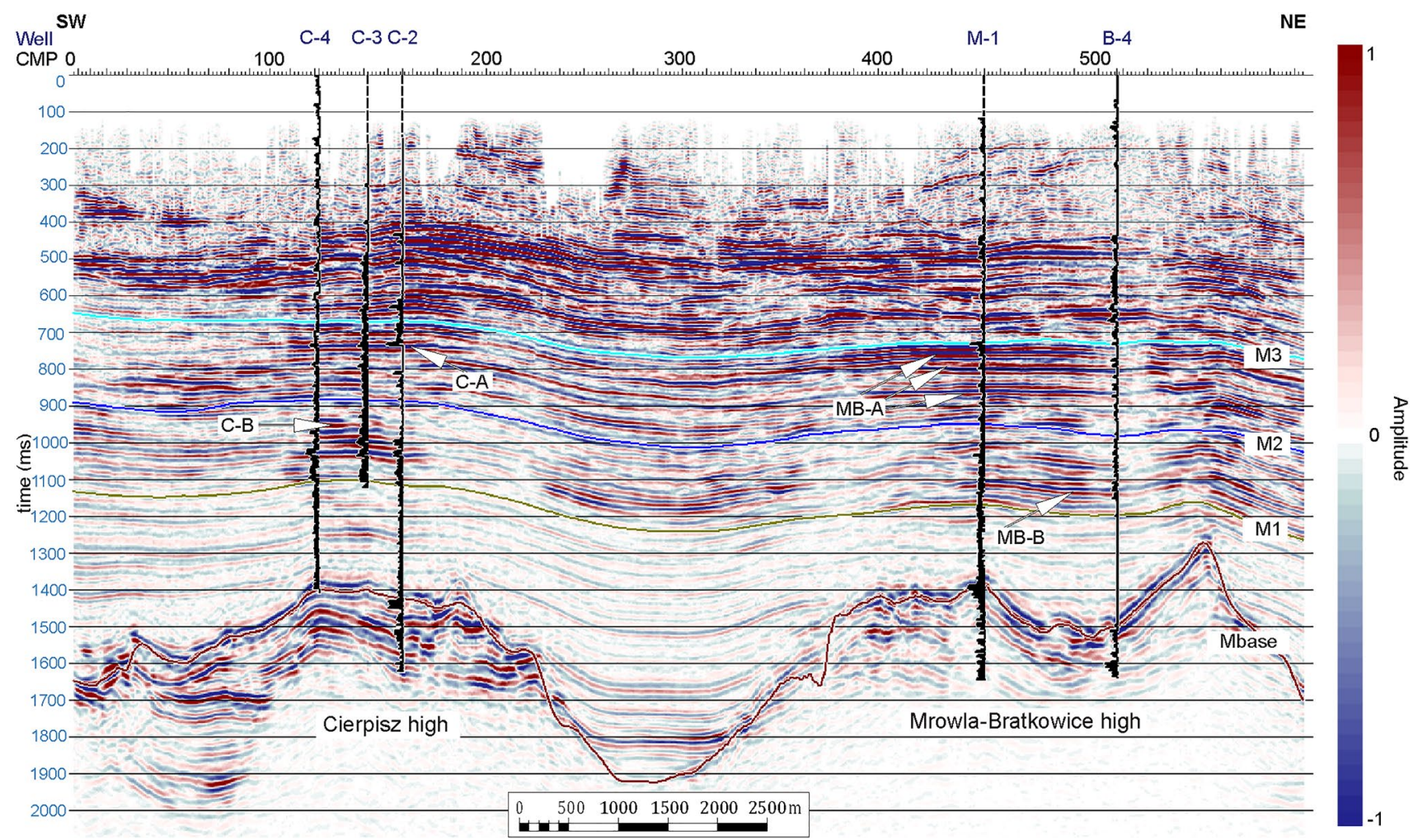

Fig. 2 Arbitrary seismic profile C-4-B-4 through the Cierpisz and Mrowla-Bratkowice highs, showing well locations (C-4, C-3, C-2, M-1 and B-4). M1, M2 and M3-horizons within Miocene sequence,

\section{Post-stack attributes}

The standard procedure used to visualize seismic anomalies caused by gas saturation is the application of seismic attributes. They are additional information obtained from seismic data, allowing visually reinforcing or quantifying the interesting features of the record. For reservoir interpretation, we used the post- and pre-stack seismic attributes. From the post-stack seismic attributes, we choose sweetness, which joins instantaneous amplitude and frequency. Areas characterized by high values of the instantaneous amplitude and low values of instantaneous frequency will give high values of sweetness. Therefore, this attribute highlights gas saturation zones but can also be an indicator of contact between clay and sand (high impedance contrast) (Yushun et al. 2011).

\section{Pre-stack attributes}

For the evaluation of the observed anomalies on post-stack data, we applied AVO analysis. AVO analysis can be defined as the variation in the amplitude of a seismic reflection with the angle of incidence or source-offset distance (Ostander 1984; Castagna and Backus 1993; Chopra and Castagna 2014).
Mbase is the pre-Miocene basement. With the arrows, the zones under analyses were marked (C-A, C-B, MB-A and MB-B). Inserted well logs are gas saturation

The method is based on Zoeppritz equations (Zoeppritz 1919) which describe seismic wave partitioning at an interface. The equations relate the amplitude of incident $\mathrm{P}$-wave to reflected and transmitted $\mathrm{P}$ - and $\mathrm{S}$-waves at a plane interface for a given angle of incidence. The changes in amplitude depend on velocity, density and Poisson's ratio changes at the interface. The AVO method is often used in unconsolidated sediments as a hydrocarbon gas indicator, because gas generally decreases Poisson's ratio which results in an increase in amplitude with incident angle/offset.

The Zoeppritz solution is difficult to be directly used for numerical applications. For this, the approximations of these solutions are commonly used. Usually, the Wiggins et al. (1983) approximations are applied:

$R(\theta) \approx A+B \sin ^{2} \theta+C \sin ^{2} \theta \tan ^{2} \theta$

where

$A=\frac{1}{2}\left(\frac{\Delta V_{\mathrm{P}}}{V_{\mathrm{P}}}+\frac{\Delta \rho}{\rho}\right)$

$B=\frac{1}{2} \frac{\Delta V_{\mathrm{P}}}{V_{\mathrm{P}}}-4\left(\frac{V_{\mathrm{S}}}{V_{\mathrm{P}}}\right)^{2} \frac{\Delta V_{\mathrm{S}}}{V_{\mathrm{S}}}-2\left(\frac{V_{\mathrm{S}}}{V_{\mathrm{P}}}\right)^{2} \frac{\Delta \rho}{\rho}$ 
$C=\frac{1}{2} \frac{\Delta V_{\mathrm{P}}}{V_{\mathrm{P}}}$

$R(\theta)$-reflection coefficient at a given angle $(\theta), V_{\mathrm{P}}-\mathrm{P}-$ wave velocity, $V_{\mathrm{S}}$-S-wave velocity, $\rho$-density, $A, B$ and $C$ are the AVO attributes. $A$ is an AVO intercept, and it refers to a reflection coefficient of zero angle of incidence. $B$ is an AVO gradient-it is a rate of change of amplitude with the increasing offset. $C$ is an AVO curvature. Each part of Eq. (1) describes different angles of incidence. The first part corresponds to the seismic response for zero angle of incidence, the second for middle angles, and the third for far angles near the critical angle $\left(>45^{\circ}\right)$.

The AVO analysis is mainly used for indicating gasbearing sandstones. Such collectors, however, may not give a classical bright spot in a seismic profile, even though they manifest AVO anomaly. For this reason, a whole classification of AVO effects registered at the top of the reservoir sequence was introduced. The basis of this classification is associated with the strength of reflection coefficient for a normal incident angle (intercept) and its changes with the increasing offsets/angles (gradient). The initial AVO classification consisted of three classes (Rutherford and Williams 1989), but it was extended to five classes of the possible AVO behaviour (Castagna and Swan 1997):

- Class I comprises high-impedance-contrast reservoirs described by high intercept and negative gradient.

- Class II is made up of near-zero-impedance reservoirs. They can be described as both weak positive (Class IIp) or negative (Class II) intercept and negative gradient.

- Class III are low-impedance reservoirs characterized by strong negative intercept and negative gradient.

- Class IV are low-impedance reservoirs characterized by strong negative intercept but a positive gradient.

In unconsolidated Tertiary clastic sediments, class I reservoirs often yields dim spots, class III and IV bright spots and class II reservoirs can be difficult to see unless they have considerable increase in gradient.

From the group of AVO pre-stack attributes, we have chosen the Product attribute which is simply a multiplication of intercept and gradient. This attribute works very well with class III responses (Rutherford and Williams 1989) which commonly occur in the Miocene formation of the Carpathian Foredeep. Unconsolidated sandstones with hydrocarbons will have a strong negative intercept and a strong negative gradient at the top and opposite on the bottom, so that they will show a positive response in the Product attribute from both top and bottom. Non-hydrocarbon-bearing sandstones will be weak or have negative Product (Avseth et al. 2010; Chopra and Castagna 2014).

The input data for AVO analysis were CDP gathers after DMO correction. The CDP gathers were not migrated before stack which results in their poor quality. The input data (Fig. 3a) have low signal-to-noise ratio; hence, before AVO analysis, it was required to perform gather conditioning (Singleton 2009). The processes used in conditioning were bandpass filtering $(8 / 16-80 / 110 \mathrm{~Hz})$, supergather creation (in a $3 \times 3 \mathrm{bin}$ ), random noise attenuation with the application of Parabolic Radon Transform (for surface wave, air wave and random noise removal) and trim statics. In Fig. 3b, angle of incidence information was extracted from the velocity model generated by utilization of sonic logs from C-2 and M-1 wells and overlaid on conditioned offset gathers. Such a plot helps in estimation if the range of angles can be meaningfully used in the AVO analysis. The maximum angles reach $50^{\circ}$. Due to the applied sequence, the substantial quality enhancement of the input data was possible. Nevertheless, signal-to-noise ratio is rather low, especially for angles greater than $40^{\circ}$. Hence, the AVO analysis was performed only within $0^{\circ}-40^{\circ}$ with twoterm Zoeppritz equations approximation (Eq. 1).

\section{Spectral decomposition}

Basis Pursuit (BP) decomposition is similar to matching pursuit algorithm that decomposes a signal in the individual functions (decomposition atoms) of the predefined dictionary (Tary et al. 2014). The theory behind matching pursuit spectral decomposition is given by Mallat and Zhanh (1993) for which the set of the predefined functions consisting of elements that differ in time and frequency is used. These functions, however, are not sine and cosine functions, as is used in the Fourier transform. The algorithm includes the step of recognition of these functions to find the optimal set of elements, which are different in time and frequency and if integrated give the original signal. In the process, the choice of a wavelet dictionary is of high importance since it predefines the accuracy of decomposition (Chen et al. 2001). Basis pursuit approach is a modified version of matching pursuit-the BP algorithm simultaneously identifies atoms and subtracts them from the signal (Zhang and Castagna 2011). Also, BP uses a minimal number of atoms of lower amplitudes, which results in a sparse representation (Chen et al. 2001).

In $\mathrm{BP}$, the signal $s(t)$ is represented as the convolution of a family of wavelets $\psi(t, n)$ and its associated coefficient series a $(t, n)$ as:

$s(t)=\sum_{n=1}^{N}[\psi(t, n) * a(t, n)]$ 

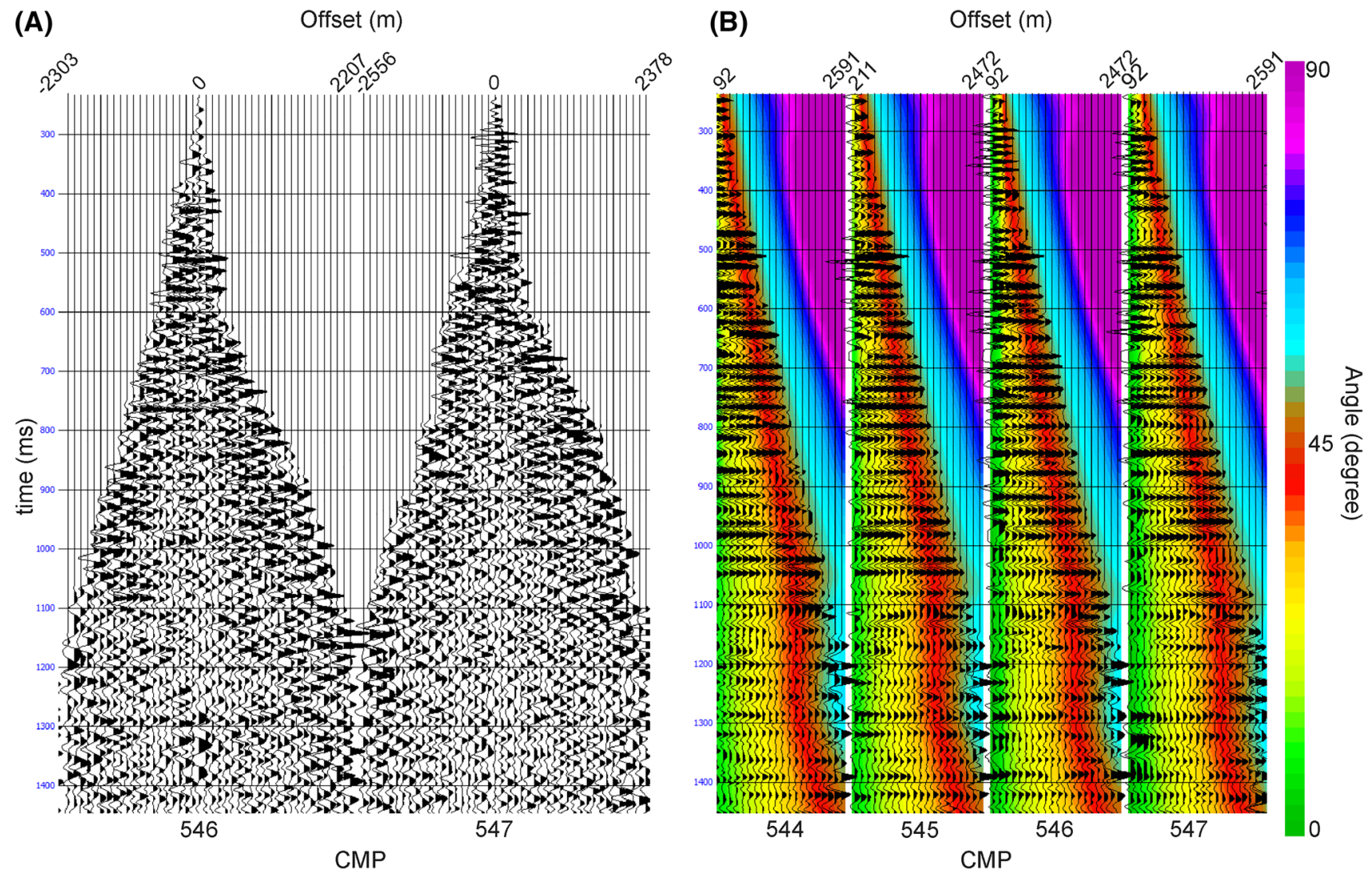

Fig. 3 a Input CMP gathers; b CMP gathers after conditioning with the angle of incidence overlaid

where $N$ is the number of atoms, $t$ is time and $n$ is the dilatation of atom $\psi(t, n)$ determining its frequency (Tary et al. 2014).

BP algorithm applied to the data set starts with the initial atom data set that is iteratively adjusted by changing atoms in the dictionary to obtain the optimal solution. The criteria used by the algorithm are based on the L1 norm.

For the decomposition, we used a dictionary consisting of Ricker wavelet with regularization parameter 0.5 (default). Regularization parameter controls the sparsity of the time-frequency maps; so the larger the parameter, the sparser the frequency map. The maximum iteration to complete the decomposition was set to 50-this, at one seismic line, took app. 15 min (on a workstation with Intel Core i7-4770 CPU @ 3.40 GHz, 32 GB RAM). For the analysis, we used frequency slices and average frequency computed based on the decomposition.

\section{Results}

In the case of non-consolidated sediments of the Carpathian Foredeep, gas saturation results in the decrease in P-wave velocity and density. Such a situation results in a local increase in reflection amplitude known as a bright spot. Nevertheless, basing only on this criterion it is problematic to differentiate between anomalies indicated within the seismic section (Fig. 2) and reason about gas saturation within these amplitude anomalies. Because of that, sweetness attribute was used for the analysis of the potential exploration sites (Fig. 4). The analysis of sweetness attribute enabled indication of continuous reflections (above M3 horizon) of higher amplitude values, which corresponds to significant impedance contrast. Between M1 and M3 horizons, several anomalous zones can be interpreted, which can be associated with gas saturation. Within the Cierpisz high, two such zones are defined: C-A (between M1 and M2 horizon) and C-B (between M2 and M3 horizon) anomalies that exhibit seismic response from the multi-layered reservoir. The gas saturation for these anomalies is validated by well-logs and adequate gas flow tests. Within Mrowla-Bratkowice high in the same stratigraphic position, two analogous zones were indicated: 


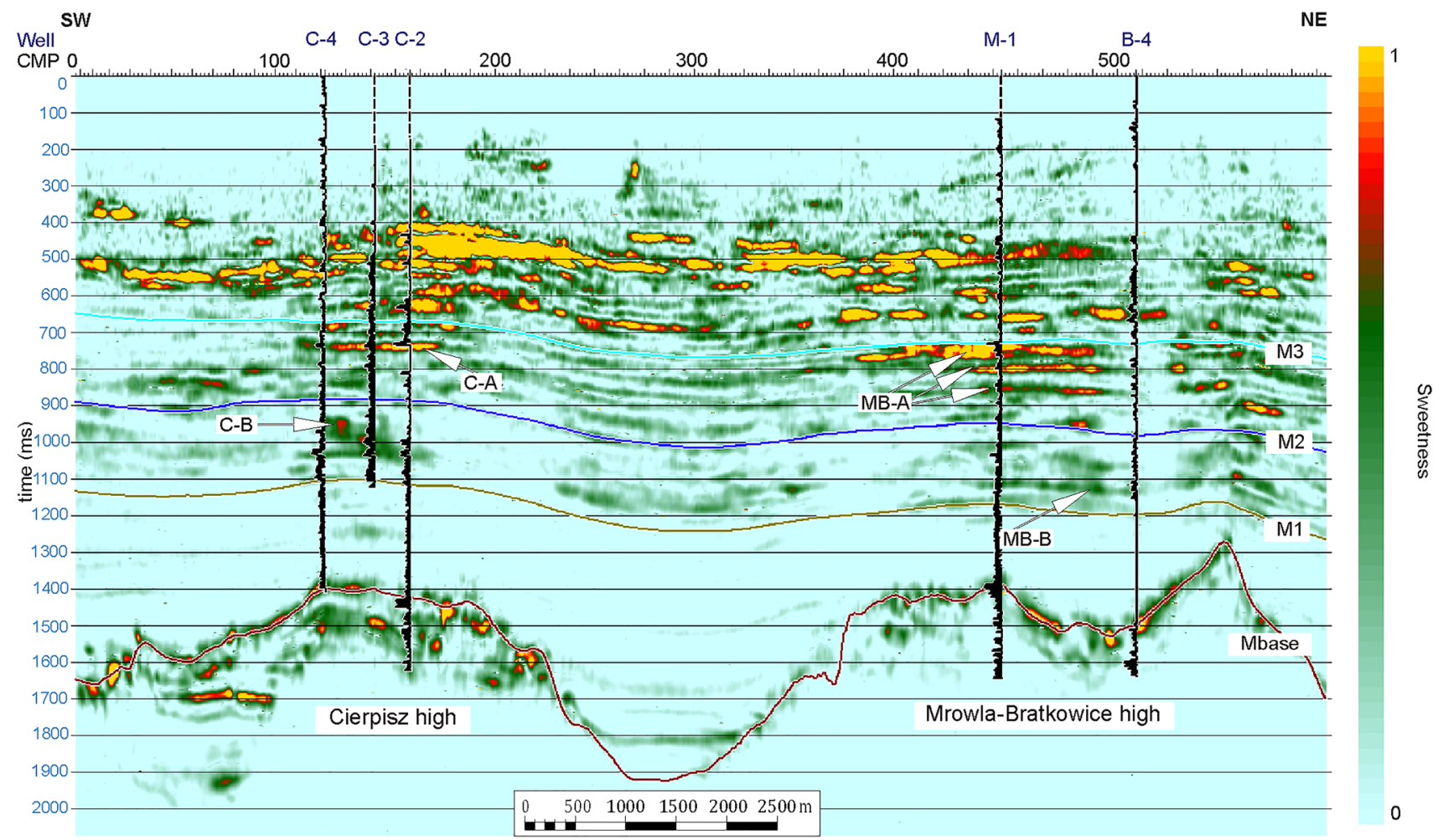

Fig. 4 Arbitrary seismic profile from Fig. 2 in sweetness attribute version. With the arrows, the zones under analyses were marked (C-A, C-B, MB-A and MB-B). Inserted well logs are gas saturation. For further description, see Fig. 2

MB-A and MB-B, which can be treated as potential gas deposits. In the vicinity of well B-4 lies an interesting non-reflective zone which is interpreted as a seismic gas chimney and was confirmed by surface geochemical measurements (Marzec et al. 2018).

\section{AVO analysis}

To verify the indicated anomalies, AVO Product was computed (Fig. 5). AVO Product gives positive values in tops and beds of gas-saturated zones. This attribute correlates well with the gas-saturated zone. Moreover, it substantially limited the range of the anomalies visible in the post-stack seismic data, especially above M3 horizon. Zones C-A and MB-A have strong positive values. Zones $\mathrm{C}-\mathrm{B}$ and MB-B are also clearly visible but manifest lower values. Cross-plots of AVO behaviour with the angle of incidence show class III response for all anomalies under analyses (Figs. 6, 7, 8, 9).

Additionally, the interpretation of AVO Product results enabled us to indicate another interesting zone that lies above the M3 horizon-flat spot at time $650 \mathrm{~ms}$ drilled by B-4 well. On this level in well B-4, gas flow was obtained. At the same level above M3 horizon, similar anomalies occur (near M-1 well and C-2), but there were no gas flow tests completed.
For further analysis and comparison between petrophysical properties and the seismic response, we juxtapositioned different types of data: well-logs, seismic data, sweetness attribute and AVO Product. To the data set, gas saturation and mudlogging were added. C-A anomaly (Fig. 10) that is visible at the time of $740 \mathrm{~ms}$ exhibits typical bright-spot signature. It is class III AVO anomaly. This anomaly correlates with mudstone-sandstone layer of the thickness of app. $12 \mathrm{~m}$ and gas saturation which reaches up to $40 \%$. The averaged porosity of this layer is $14 \%$. According to the well-log data, this interval has no gas flows tests completed, but drilling mud exhibited gas. Below the analysed layer, there exists thick sandstone of thickness of about $50 \mathrm{~m}$ that can be correlated within the whole 3D data volume. It has a porosity of app. $22 \%$ but shows no gas saturation.

C-B anomaly (Fig. 10) is a seismic image of the multihorizon gas reservoir which is currently exploited. In the seismic image (Figs. 2, 4), this zone manifests itself between times $920-1110 \mathrm{~ms}$ as bright spots and flat spots that correspond to the subsequent gas-bearing horizons that also exhibit class III AVO. These intervals are built of heterolithic deposits, within which both thin sandstone layers, of porosity reaching $17 \%$, and mudstone intervals, of very low porosity, are gas-saturated. 


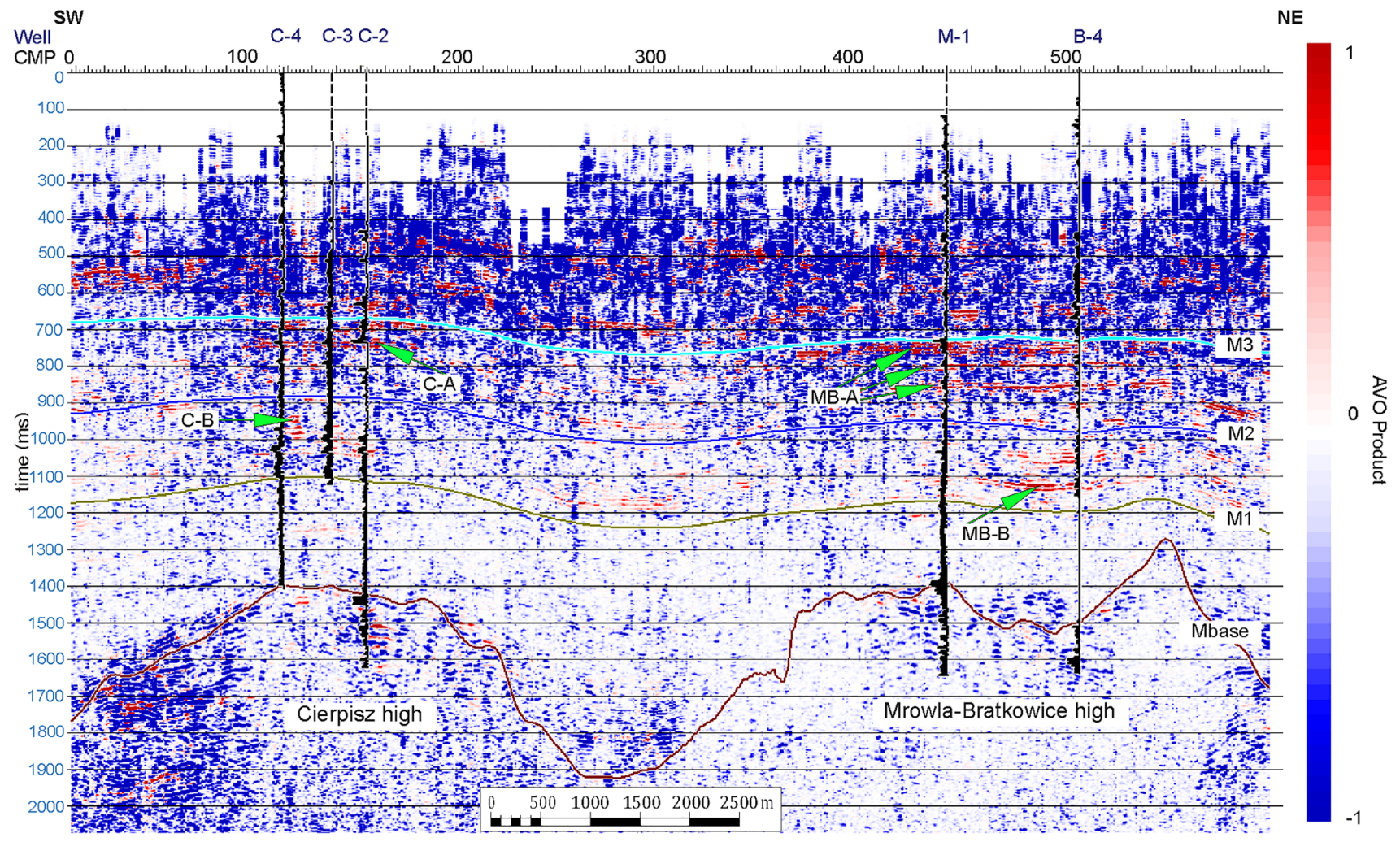

Fig. 5 Arbitrary seismic profile from Fig. 2 in AVO Product attribute version. With the arrows, the zones under analyses were marked (C-A, C-B, MB-A and MB-B). Inserted well logs are gas saturation. For further description, see Fig. 2

(A)

$$
\text { CMP } 129
$$

offset (m) 33380612821758

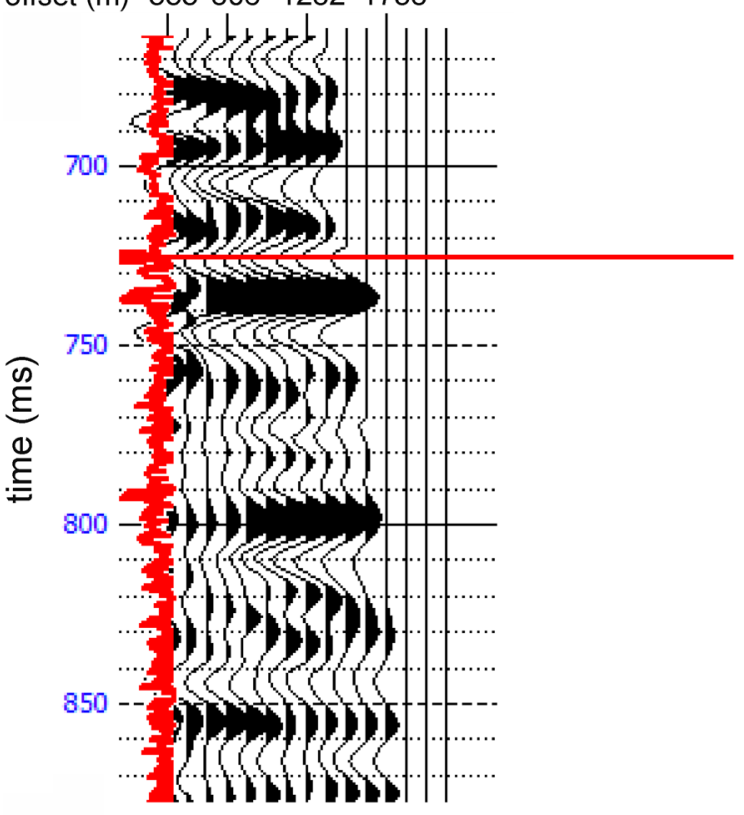

(B)

Correlation $=0.8894$

$A=-1438, B=-6692$

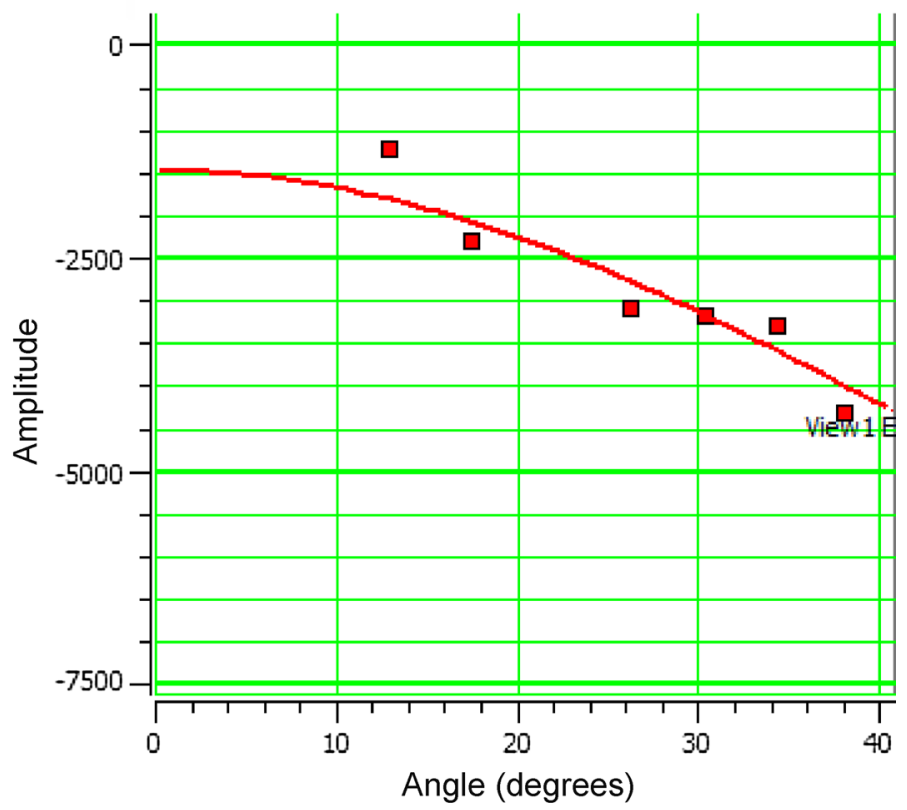

Fig. 6 AVO analysis of C-A anomalous zone: a gather under analysis overlaid with gas saturation log from well C-2; b crossplot of AVO behaviour with the angle of incidence showing III class response 
(A) CMP 146

offset (m) 211687116316392115

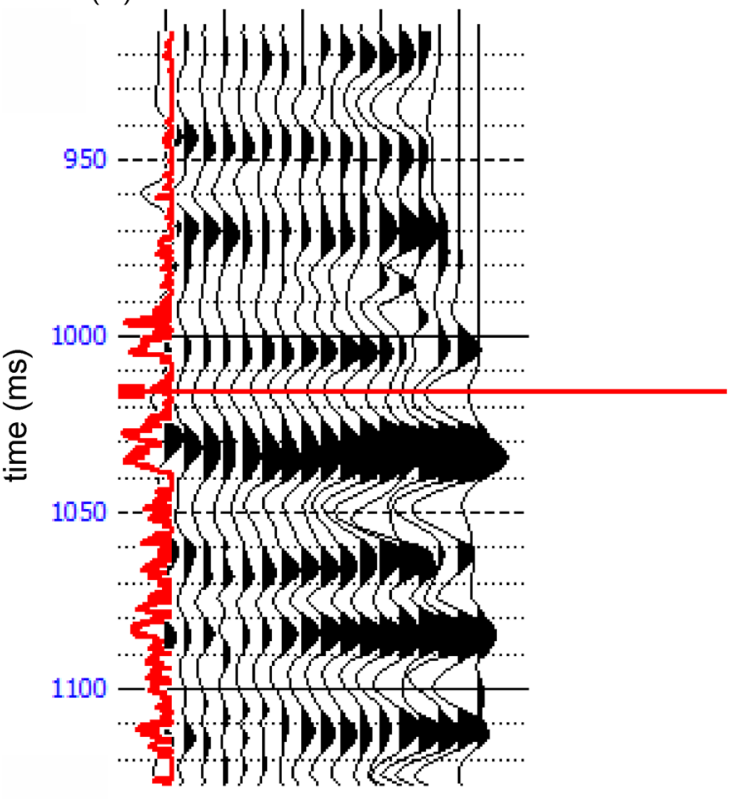

(B)

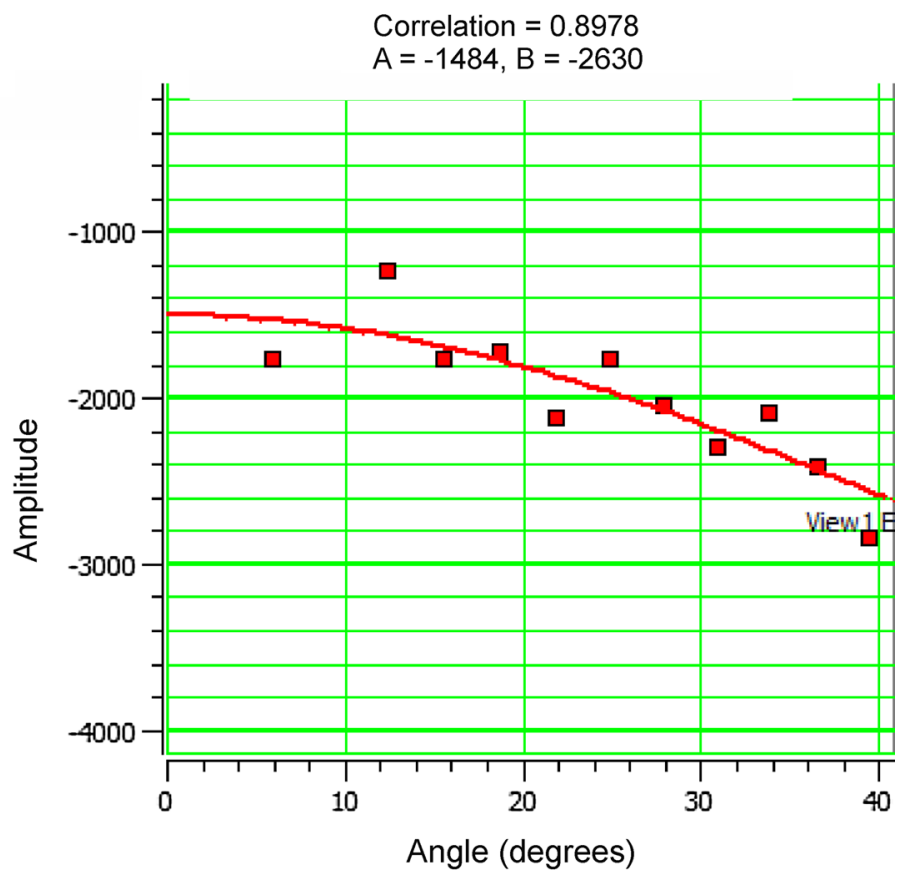

Fig. 7 AVO analysis of C-B anomalous zone: a gather under analysis overlaid with gas saturation log from well C-2; b crossplot of AVO behaviour with the angle of incidence showing III class response

(A)

CMP 431

offset (m) 211568925140118772353

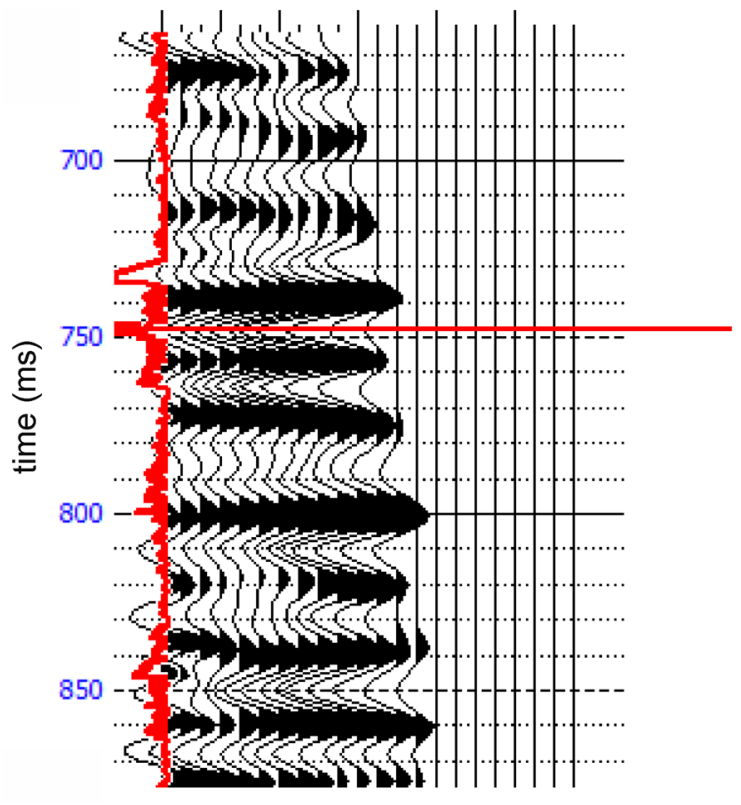

(B)

Correlation $=0.9597$

$A=-4573, B=-10434$

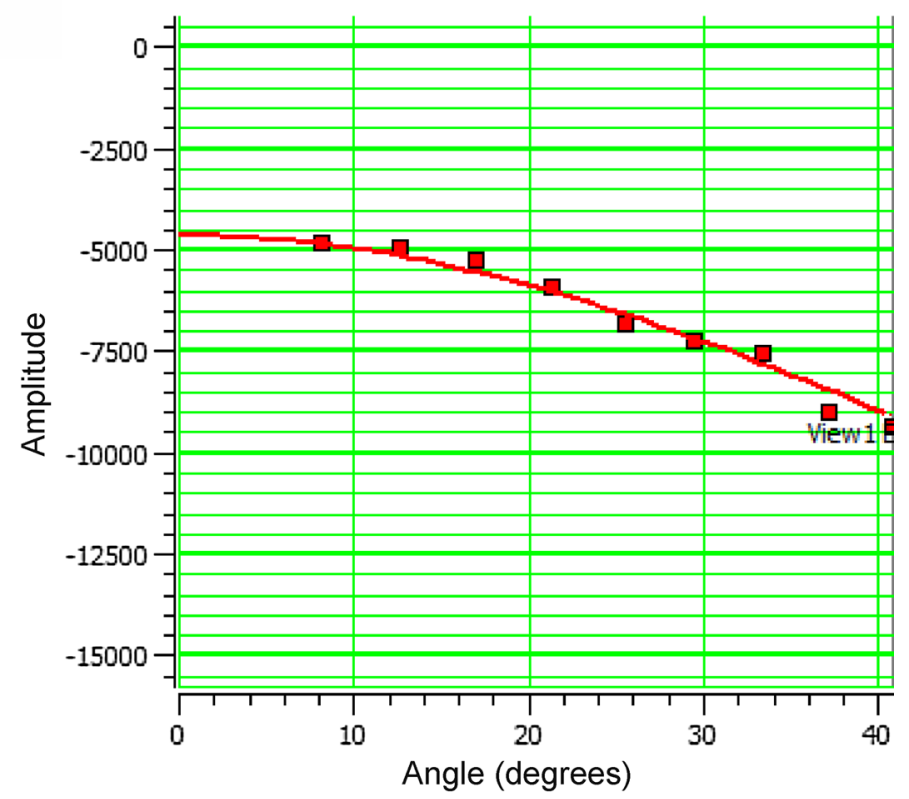

Fig. 8 AVO analysis of MB-A anomalous zone: a gather under analysis overlaid with gas saturation log from well M-1; b crossplot of AVO behaviour with the angle of incidence showing III class response 
(A)

CMP 468

offset (m) 3306871163163921152591

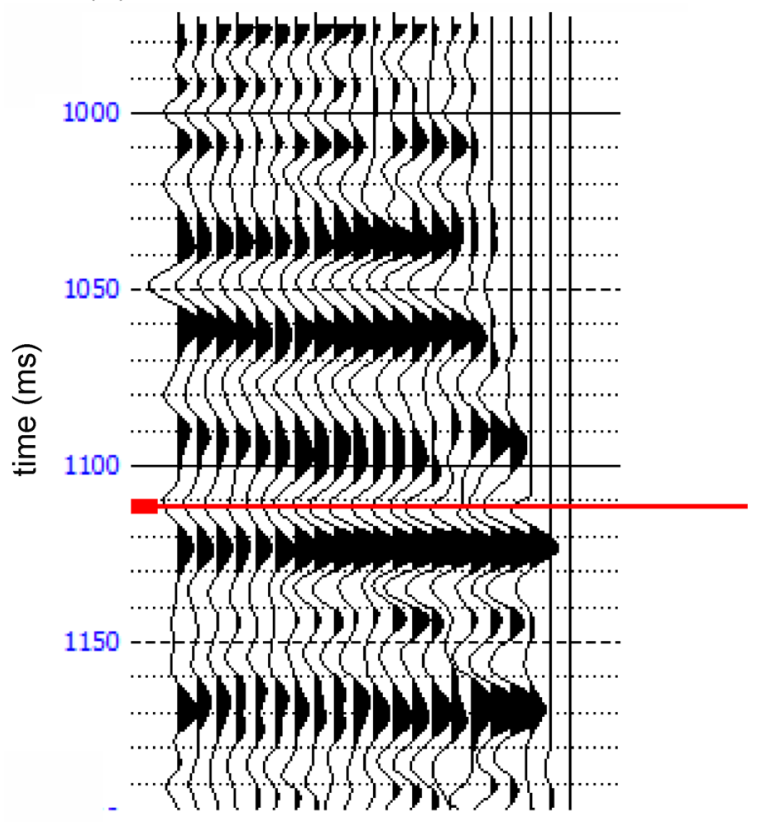

(B)

Correlation $=0.8108$

$A=-1590, B=-5707$

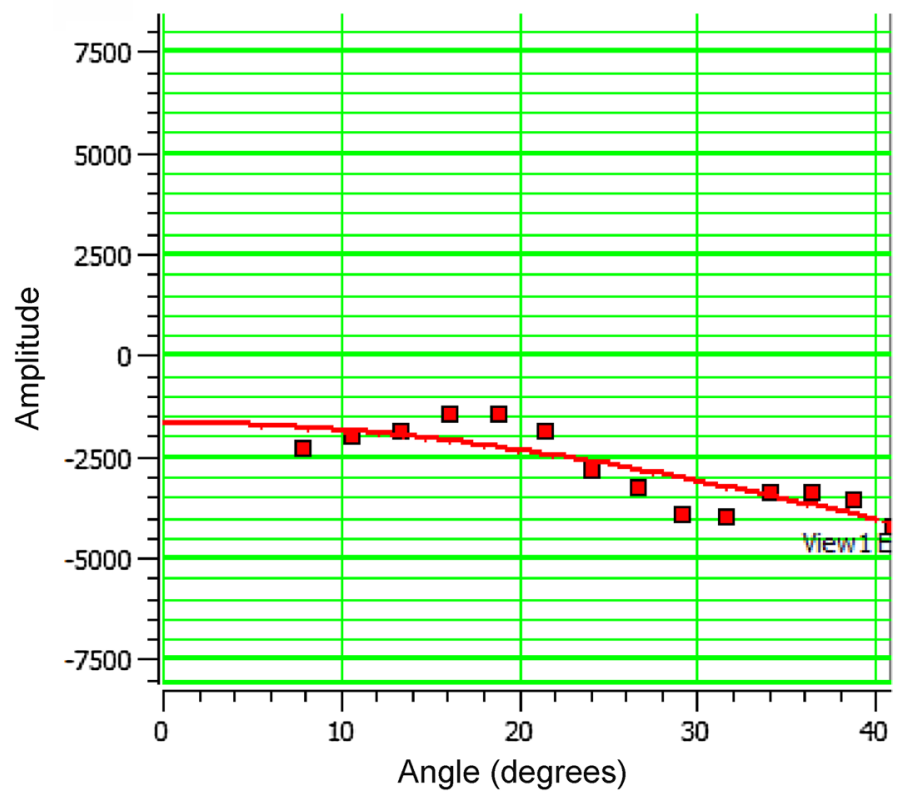

Fig. 9 AVO analysis of MB-B anomalous zone: a gather under analysis; $\mathbf{b}$ crossplot of AVO behaviour with the angle of incidence showing class III response

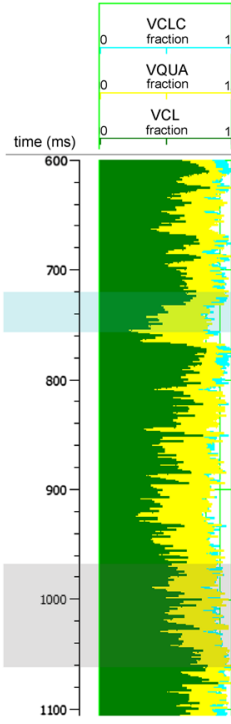

(A)

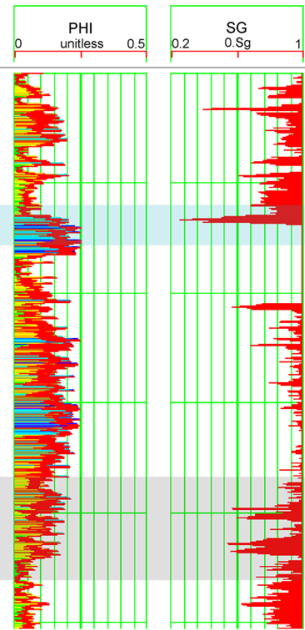

(B)

(C)

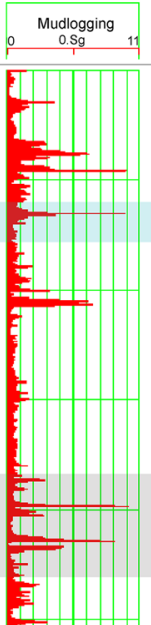

(D)

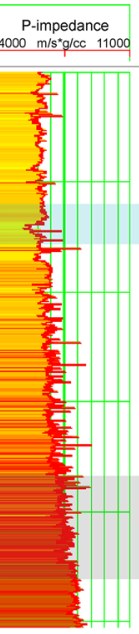

(E)

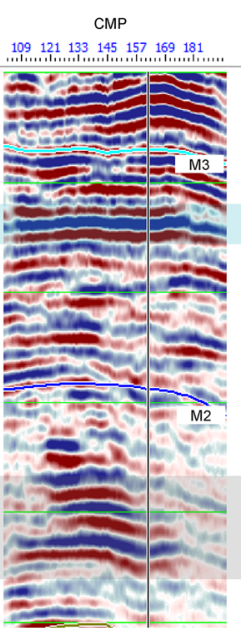

(F)

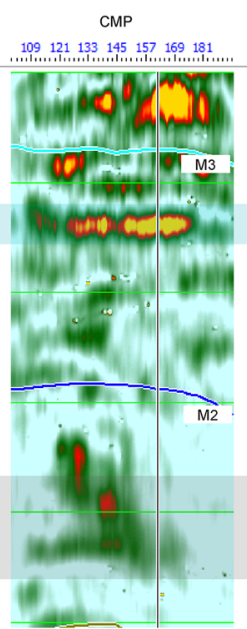

(G)

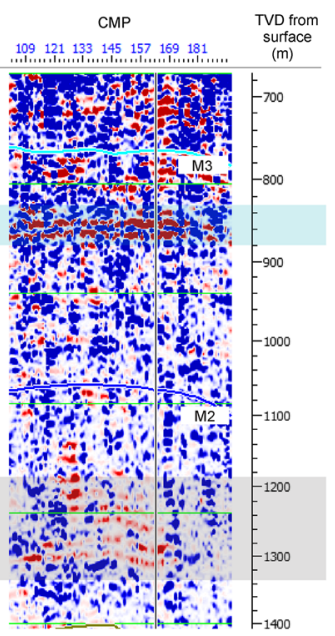

(H)

Fig. 10 Well C-2. From the left: a lithology, b porosity, $\mathbf{c}$ gas saturation, $\mathbf{d}$ mudlogging, e P-wave impedance, $\mathbf{f}$ seismic data, $\mathbf{g}$ sweetness, $\mathbf{h}$ AVO product. Blue indicates C-A anomaly, grey C-B anomaly. Well trajectory is marked on the seismic data

The anomalous zone MB-A (Fig. 11) spans the time between 720 and $870 \mathrm{~ms}$, where the seismic image shows bright spots and flat spots. Within this interval lie three anomalies that all give class III AVO response. These anomalies correlate well with zones of higher gas saturation (reaching about 20\%). These anomalies correspond with mudstones of low porosity, not exceeding $8 \%$. Zones of better petrophysical qualities that intrabed anomalies exhibit no gas saturation. 


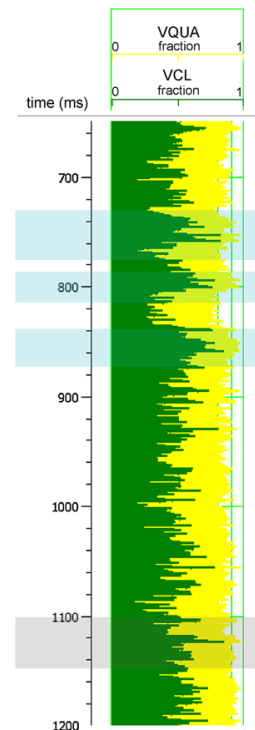

(A)

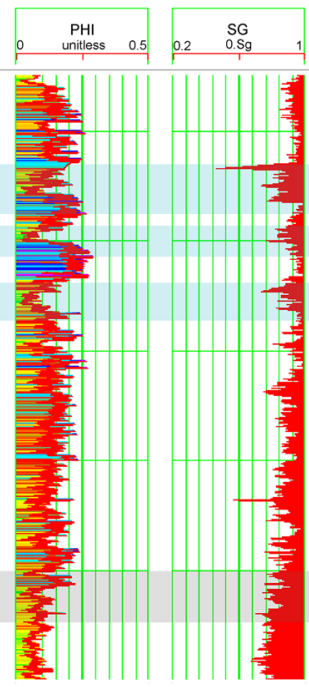

(C)

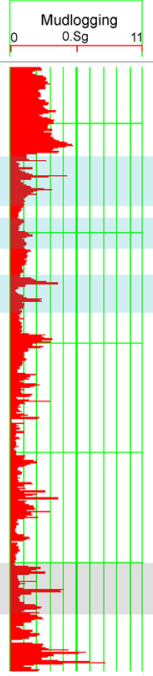

(D)

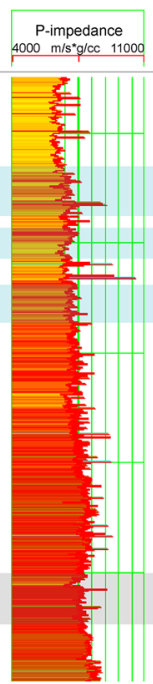

(E)

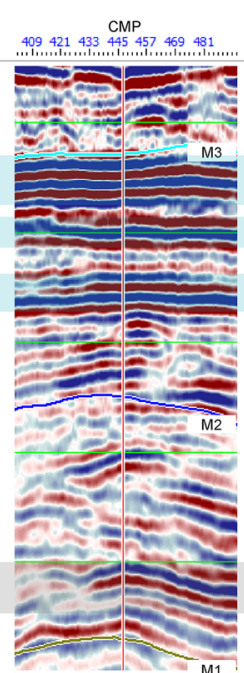

(F)

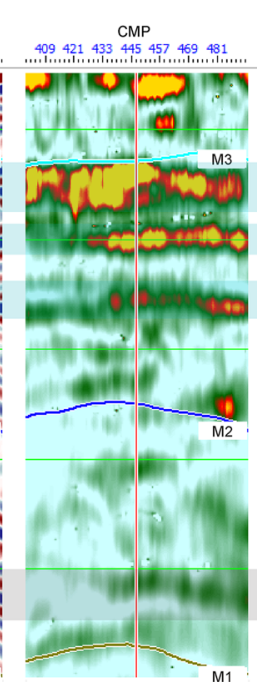

(G)

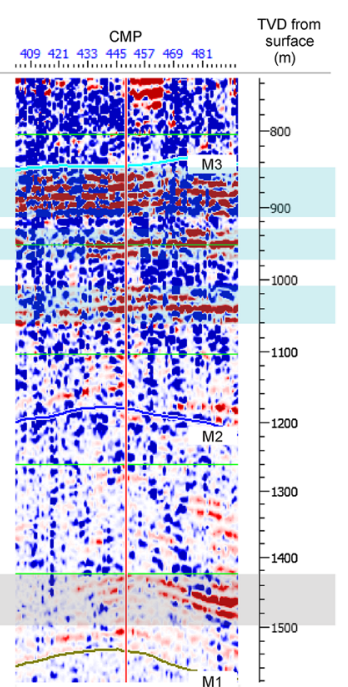

(H)

Fig. 11 Well M-1. From the left: a lithology, $\mathbf{b}$ porosity, $\mathbf{c}$ gas saturation, $\mathbf{d}$ mudlogging, e P-wave impedance, $\mathbf{f}$ seismic data, $\mathbf{g}$ sweetness, $\mathbf{h}$ AVO product. Blue indicates MB-A anomaly, grey MB-B anomaly. Well trajectory is marked on the seismic data

The anomalous zone MB-B (Fig. 11) lies between wells M-1 and B-4. It gives clear, bright spots at times 1030-1170 ms. These anomalies also give class III AVO response. These zones, due to their localization, cannot be tied to wells. They can be associated with the top of the heterolithic sequence which has higher mudstone content with thin layers of higher sandstone additives. Similar to the previous cases, gas saturation is higher in mudstone of lower porosity, than in sandstone.

\section{Spectral decomposition}

Results of spectral decomposition are shown in Figs. 12, 13 and 14. We define five zones for which we perform qualitative interpretation. For comparison, we chose three frequency slices: low (20 Hz-Fig. 12), middle ( $40 \mathrm{~Hz}-$ Fig. 13) and high (60 Hz-Fig. 14). The colour scale is unified for these figures and shows the distribution of amplitudes for a given frequency. Zones connected with Cierpisz region (C-A and C-B) exhibit the highest amplitudes corresponding to lower frequencies. In both zones, there exists a gas reservoir. The most prominent low-frequency anomaly is associated with C-B zone; for this case also, high frequencies are not represented very well (compare zone C-B at $60 \mathrm{~Hz}$ in Fig. 14). The upper laying reservoir (zone C-A) manifests high amplitudes for low frequencies as well as for high frequencies. This may be attributed to the gas saturation and existence of more finely layered reservoirs. The presence of gas attenuates high frequencies, and this effect can result in higher amplitudes of lower frequencies in regard to the high-frequency amplitudes. On the other hand, thin beds add to the tuning effect which manifests itself by the interference of reflections and hence higher frequencies. Well-logs interpretation exhibits the presence of finely layered heterolithic intervals for the region C-B.

Zones associated with the Mrowla-Bratkowice region (MB-A and MB-B) show a slightly different response. MB-A zone does not show increased amplitudes for $20 \mathrm{~Hz}$ frequency slice (Fig. 12), but it gives very high amplitudes for the 40 and $60 \mathrm{~Hz}$ ones (Figs. 13, 14, respectively). AVO and seismic attribute analysis enable the interpretation of gas reservoir, but saturation had not been proven due to the lack of a test for gas flow in this interval. The lack of lowfrequency component could be associated with the existence of thin beds-in comparison with other zones, MB-A is built by the most finely layered interval.

Zone MB-B, although showing preferable characteristic for gas saturation on AVO and attribute analysis, in spectral decomposition shows no differentiation for lower and higher frequencies. This gives arguments to reason that the zone cannot be treated as a possible prospecting target.

The last zone which is worth mentioning is the shallowest zone near well B-4 (marked by black arrow on Figs. 12, 13, 14). For this, the test for a gas flow gave positive results. This anomaly manifests also high amplitudes for lower frequencies, similar to zone C-A. Lithological characteristics for these two are also similar-both zones are built by heterolithic sequences. Such characteristics classify the B-4 anomaly as a potential exploration site. 


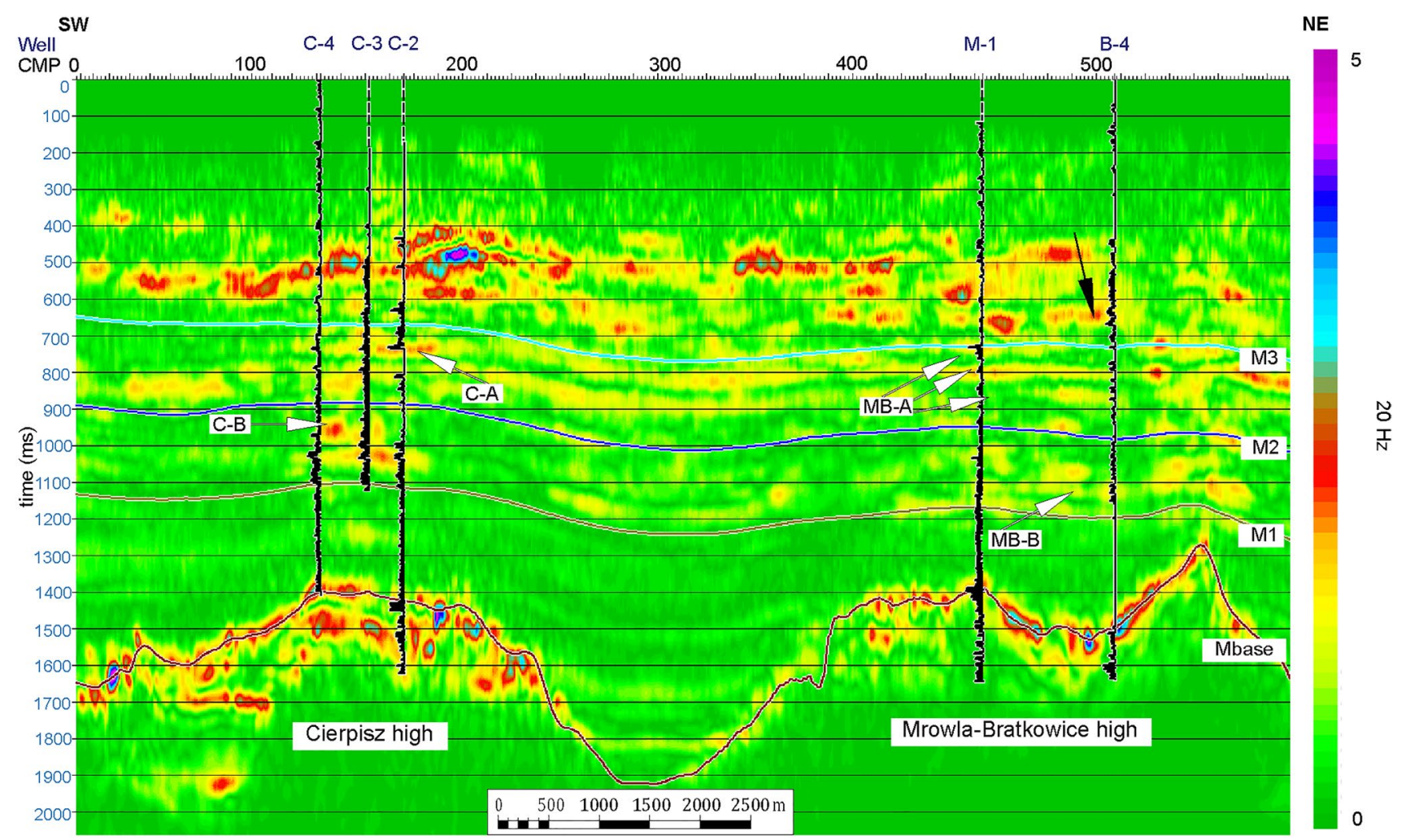

Fig. 12 Arbitrary seismic profile from Fig. 2 in spectral decomposition $20 \mathrm{~Hz}$ frequency volume. With the arrows, the zones under analyses were marked (C-A, C-B, MB-A and MB-B). Inserted well logs

\section{Discussion}

The analysed anomalous zones C-A and MB-A are localized within one seismic facies that belongs to the deltaic sediments (Marzec et al. 2018). Both these zones are composed out of heterolithic sequences that are built out of several-dozen metres of intervals of mudstone and sandstone sequences of various ratios. Anomalous zones C-B and MB-B are localized within deeper deltaic sediments. These heterolithic intervals manifest more mudstone additives. Within Cierpisz high, gas saturation is generally present within heterolithic sequences of high sand additives and better petrophysical quality.

The zone associated with Mrowla-Bratkowice high is characterized by higher amplitudes and more prominent anomalies than Cierpisz high, which may indicate better reservoir properties. Nevertheless, after drilling of well M-1, it turn out that the interval exhibits very strong heterolithic character, with weak gas saturation, flows from almost all intervals within the Miocene sediments that are linked to very thin mudstone layers. Sandstone layers that have far better petrophysical parameters have no gas saturation. This scenario may be attributed to the thin bedded mudstone source rock from which the generated gas migrated are gas saturation. Black arrow indicates interesting shallow zone. For further description, see Fig. 2

directly to a very thin sandstones within the heterolithic sequence or stayed within source rock.

AVO anomalies correlate well with the gas-saturated intervals. All zones exhibit class III AVO anomalyresponse characteristic for gas-bearing sandstones of good reservoir properties, though they are produced by heterolithic sequences that consist of thinly layered mudstones and sandstones. Such anomalies are also indicated outside the gas-bearing zones. The existence of the false anomalous zones may be a result of the non-optimal processing sequence and the specification of land seismic and acquisition parameters. Non-regular offset distribution results in the weakening of amplitudes for near offsets, low $\mathrm{S} / \mathrm{N}$ ratio or strong surface wave that is not reduced from the final data may cause amplitude changes, for which AVO analysis is very sensitive (Castagna and Backus 1993; Downton et al. 2000; Chopra and Castagna 2014; Cichostępski et al. 2019a, b). The existence of AVO anomalies may also be a result of geological features such as uneven compaction of clastic sediments, rapid change in $V_{\mathrm{P}} / V_{\mathrm{S}}$ ratio that can be related to lithofacial changes rather than gas saturation and thin beds that can cause tuning effect. Tuning may result in amplification of AVO results which can influence reservoir reasoning 


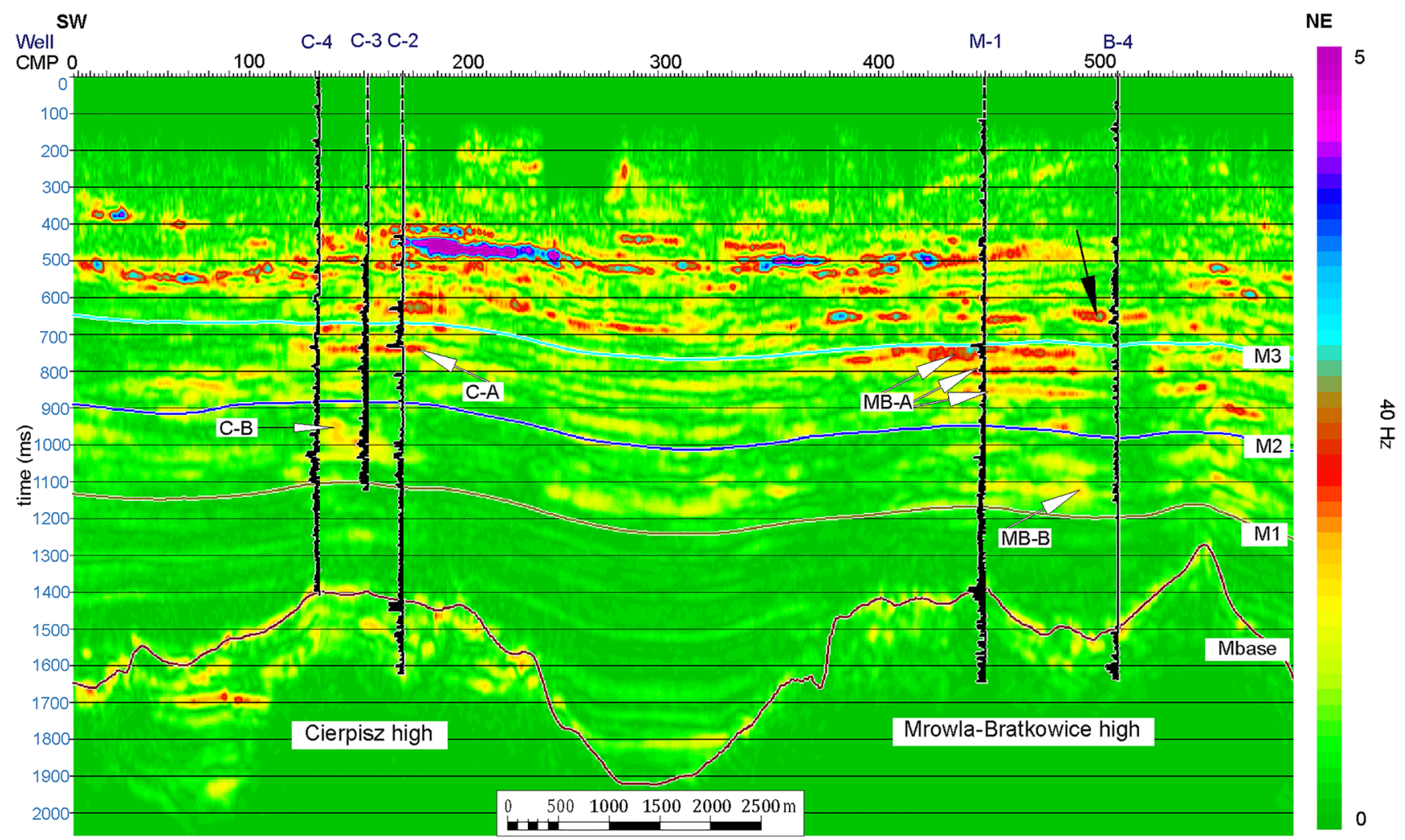

Fig. 13 Arbitrary seismic profile from Fig. 2 in spectral decomposition $40 \mathrm{~Hz}$ frequency volume. With the arrows, the zones under analyses were marked (C-A, C-B, MB-A and MB-B). Inserted well logs

(Castoro et al., 2001; Yang 2003). AVO anomalies can be produced by mudstones or sandstones, with no difference for thin or thick sequences. For this reason, it is crucial to use other methods that can differentiate between the thicknesses of the reservoir, for example spectral decomposition.

Spectral decomposition can be a good indicator of thin bed thickness (Partyka et al. 1999), but its quantitative ability is mostly useful for modelling purposes, i.e. give accurate results for a simple wedge model (Kwietniak 2016). Nevertheless, the selective attenuation caused by gas-saturated zones sometimes exhibits higher spectral amplitudes for lower frequencies. At the same time, frequency analysis is a reliable tool for an indication of tuning effect that limits AVO analysis. With the application of spectral decomposition, we can distinguish between the frequency characteristics of the seismic anomalies that give the same bright-spot signature on the post-stacked seismic data. Anomalies that exhibit higher amplitudes for lower frequencies are classified as gas-bearing zones. Those anomalies that are associated with higher frequencies are interpreted as consisting of more finely layered heterolithic sequences. For this reason, the later are treated with lower reliability when it comes to AVO analysis. are gas saturation. Black arrow indicates interesting shallow zone. For further description, see Fig. 2

Anomalies that lie above the Mrowla-Bratkowice high are identified as caused by tuning effect and hence should be excluded from reservoir reasoning. The application of frequency analyses enabled us to differentiate anomalies in terms of thickness relation of layers that lie within them.

\section{Conclusions}

The performed analysis included two structural highs of the Miocene sediments: Cierpisz and Mrowla-Bratkowice. Within the Cierpisz high, there is a multi-layered gas reservoir, Mrowla-Bratkowice high and anomalies that lie within this area are not classified as possible gas reservoirs even though the geological setting is similar to the Cierpisz high.

$\mathrm{AVO}$ analysis indicates possible gas-saturated zones that are verified by well logs and gas flow tests. They occur for both sandstones and mudstones as well as for the heterolithic sequence that complicates indication of the source and reservoir rock.

AVO anomalies can be also a result of wave interference; hence, it is crucial to perform a tuning analysis for the local geological setting. Spectral decomposition analysis shows that anomalies that are associated with the 


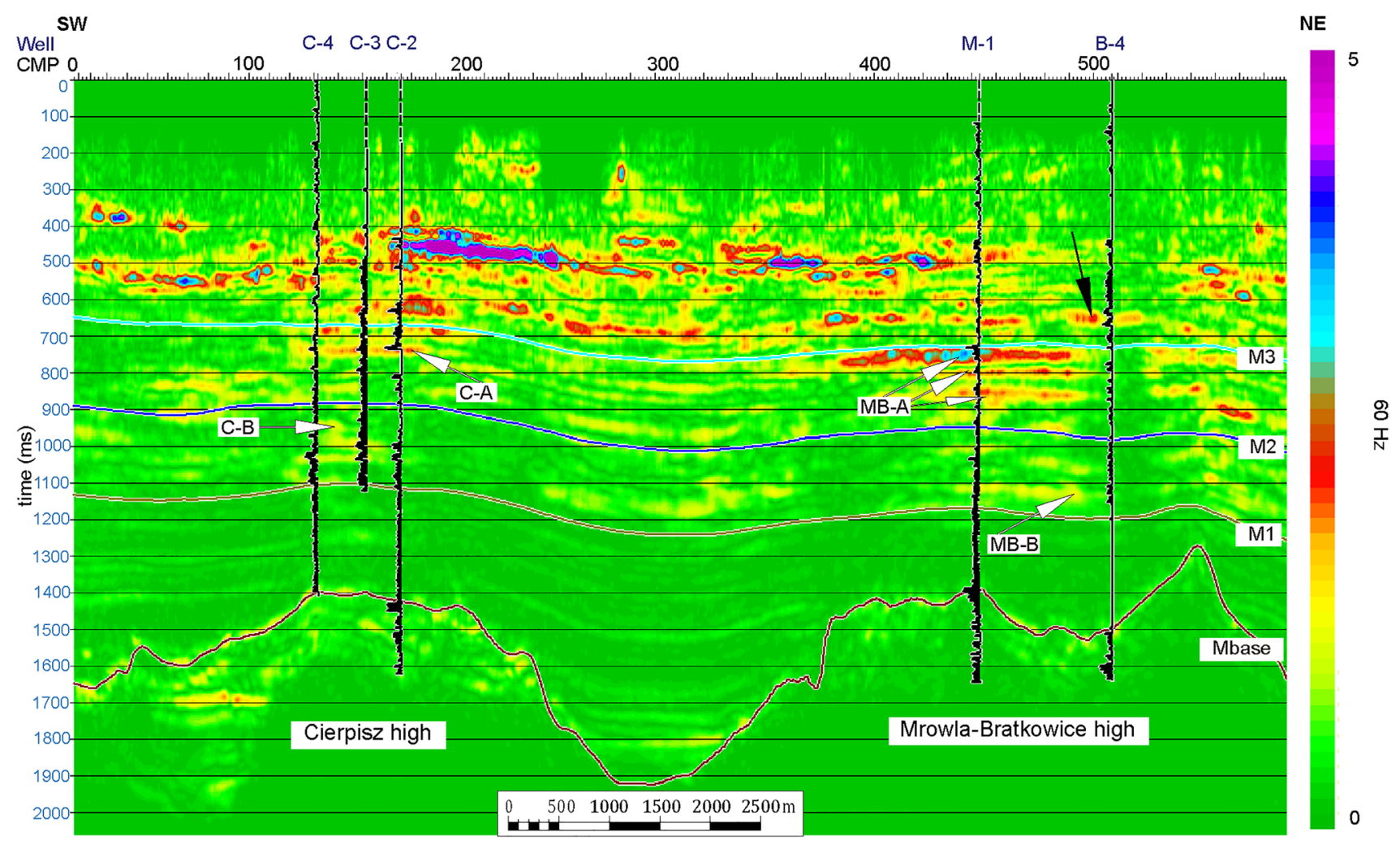

Fig. 14 Arbitrary seismic profile from Fig. 2 in spectral decomposition $60 \mathrm{~Hz}$ frequency volume. With the arrows, the zones under analyses were marked (C-A, C-B, MB-A and MB-B). Inserted well logs are gas saturation. Black arrow indicates interesting shallow zone. For further description, see Fig. 2
Mrowla-Bratkowice high are characterized by relatively higher frequencies than those of the Cierpisz high. This pattern may suggest that anomalies above the Mrowla-Bratkowice high are more likely linked to the tuning effect, than to the gas saturation. Moreover, those anomalies do not exhibit substantial low-frequency characteristics, which is one of the diagnostic indicators for gas saturation.

Based on the obtained results, authors suggest comprehensive seismic interpretation for gas exploration by application of post- and pre-stack attributes together with spectral analysis of indicated anomalous zones within thin beds. Altogether with the seismic analysis, it is crucial to perform integrated geological analysis that enables to recover basin morphology and sedimentological history. Only such an approach can explain the distribution of gas saturation in a given sedimentary basin. Our current work is focused on seismic stratigraphy within the area of studies and its proximity, altogether with the seismic analysis. For the Miocene strata of the Carpathian Foredeep, only such a methodology will give reliable results that will enable reservoir reasoning.

Acknowledgements The research was supported by the National Science Centre (NCN) via Grant N525 254040 awarded to Porębski SJ and AGH-UST University of Science and Technology in Krakow, Poland, Grant No. 11.11.140.645. We thank Polish Oil and Gas Company (PGNiG) for providing access to the seismic and well-log data set and CGG for their provision of seismic interpretation software through the University Software Grant Program. We would also like to thank Mariusz Majdański and other anonymous reviewer for providing valuable and insightful feedback on the manuscript.

\section{Compliance with ethical standards}

Conflict of interest On behalf of all authors, the corresponding author states that there is no conflict of interest.

Open Access This article is distributed under the terms of the Creative Commons Attribution 4.0 International License (http://creativeco mmons.org/licenses/by/4.0/), which permits unrestricted use, distribution, and reproduction in any medium, provided you give appropriate credit to the original author(s) and the source, provide a link to the Creative Commons license, and indicate if changes were made. 


\section{References}

Ahmad SS, Brown RJ, Escalona A, Rosland BO (2017) Frequencydependent velocity analysis and offset-dependent low-frequency amplitude anomalies from hydrocarbon-bearing reservoirs in the southern North Sea, Norwegian sector. Geophysics 82:N51-N60

Allen JL, Peddy CP, Fasnacht TL (1993) Some AVO failures and what (we think) we have learned. Lead Edge 12(3):162

Avseth P, Mukerji T, Mavko G (2010) Quantitative seismic interpretation: applying rock physics tools to reduce interpretation risk. Cambridge University Press, Cambridge

Bała M, Cichy A (2007) Comparison of P-wave and S-wave velocities estimation from Biot-Gassmann and Kuster-Toksoz models with results obtained from acoustic wavetrains interpretation. Acta Geophys 55:222-230

Barnes AE (1991) Comments on instantaneous frequency. SEG Technical Program

Biot MA (1956) Theory of propagation of elastic waves on a fluid saturated porous solid. Low frequency range. J Acoust Soc Am 28(2):168-191

Castagna JP, Backus MM (1993) AVO analysis-tutorial and review. In: Castagna JP, Backus MM (eds) Offset-dependent reflectivity-theory and practice of AVO analysis. Society of Exploration Geophysics, Tulsa, pp 3-37

Castagna JP, Swan HW (1997) Principles of AVO crossplotting. Lead Edge 16:337-342

Castoro A, White RE, Thomas RD (2001) Thin-bed AVO: compensating for the effects of NMO on reflectivity sequences. Geophysics 66(6): 1714-1720

Chen S, Donoho DL, Saunders MA (2001) Atomic decomposition by basis pursuit. SIAM Rev 43:129-159

Chopra S, Castagna JP (2014) AVO. Society of Exploration Geophysis, Tulsa

Cichostępski K (2016) Analiza zmian zapisu sejsmicznego z offsetem jako narzędzie do identyfikacji stref akumulacji gazu zmiemnego w cienkowarstwowych utworach zapadliska przedkarpackiego. Dissertation, AGH Univesity of Science and Technology in Krakow. http://winntbg.bg.agh.edu.pl/rozprawy2/11172/full11172. pdf. Accessed 17 June 2019

Cichostępski K, Dec J, Kwietniak A (2019a) Relative amplitude preservation in high-resolution shallow reflection seismic: a case study from Fore-Sudetic Monocline, Poland. Acta Geophys 67:77-94

Cichostępski K, Dec J, Kwietniak A (2019b) Simultaneous inversion of shallow seismic data for imaging of sulfurized carbonates. Minerals 9:203

Downton JE, Russell HB, Lines LR (2000) AVO for managers: pitfall and solutions. CREWES Research Report Volume 12

Korneev VA, Golshubin GM, Daly TM, Silin DB (2004) Seismic lowfrequency effects in monitoring fluid-saturated reservoirs. Geophysics 69:522-532

Kotarba M (1998) Composition and origin of gaseous hydrocarbons in the Miocene strata of the Polish part of the Carpathian Foredeep. Przegląd Geol 46:751-758

Kotarba MJ, Więcłąw D, Kosakowski P, Kowalski A (2005) Potencjał węglowodorowy skał macierzystych i geneza gazu ziemnego akumulowanego w utworach miocenu zapadliska przedkarpackiego w strefie Rzeszowa. Przegląd Geol 53:67-76

Kwietniak A (2016) Spectral decomposition of a seismic data-thin bed thickness estimation and analysis of attenuating zones, Doctoral Thesis, Hard copy in Library of AGH-UST, Access www. bg.agh.edu.plDissertation, AGH-UST University of Science and Technology

Li Y, Zheng X (2008) Spectral decomposition using Wigner-Vile distribution with applications to carbonate characterization. Lead Edge 27:1050-1057
Mallat SG, Zhanh Z (1993) Matching pursuit with time-frequency dictionaries. IEEE Trans Signal Process 41(12):3397-3415

Marzec P, Sechman H, Kasperska M, Cichostępski K, Guzy P, Pietsch K, Porębski SJ (2018) Interpretation of a gas chimney in the Polish Carpathian Foredeep based on integrated seismic and geophysical data. Basin Res 30:210-227

Myśliwiec M (2004a) Poszukiwania złóż gazu ziemnego w osadach miocenu zapadliska przedkarpackiego na podstawie interpretacji anomalii sejsmicznych-podstawy fizyczne i dotychczasowe wyniki. Przegląd Geol 52:299-306

Myśliwiec M (2004b) Typy pułapek gazu ziemnego i strefowość występowania ich złóż w osadach wschodniej części zapadliska przedkapackiego. Przegląd Geol 52:657-664

Myśliwiec M, Borys Z, Bosak B, Liszka B, Madej K, Maksym A, Oleszkiewicz AK, Pietrusiak M, Plezia B, Staryszak G, Świętnicka G, Zielińska C, Zychowicz K, Gliniak P, Florek R, Zacharski J, Urbaniec A, Górka A, Karnkowski P, Karnkowski PH (2006) Hydrocarbon resources of the Polish Carpathian Foredeep: Reservoirs, traps, and selected hydrocarbon fields. In Golonka J, Picha FJ (eds) The Carpathians and their foreland: geology and hydrocarbon resources. AAPG Memoir, vol 84, pp 351-393

Ostander WJ (1984) Plane-wave reflection coefficients for gas sands at non-normal angles of incidence. Geophysics 49:1637-1648

Oszczypko N (2006) Powstanie i rozwój polskiej części zapadliska przedkarpackiego. Przegląd Geol 54:396-403

Partyka G, Gridley J, Lopez J (1999) Interpretational applications of spectral decomposition in reservoir characterization. Lead Edge 18:353-360

Paszkowski M, Porębski SJ, Warchoł M (2009) Koncepcja projektu otworu kierunkowego w mioceńskich utworach zapadliska przedkarpackiego. Wiadomości Naftowe i Gazownicze 3:4-13

Reineck HE, Wunderlich F (1968) Classification and orientation of flaser and lenticular bedding. Sedimentology 11:99-104

Rutherford SR, Williams RH (1989) Amplitude-versus-offset variations in gas sands. Geophysics 54:680-688

Shixin Z, Xingyao Y, Guazanghi Z (2011) Dispersion-dependent attribute and application in hydrocarbon detection. J Geophys Eng 8:498-507

Singleton S (2009) The effect of seismic data conditioning on pre-stack simultaneous impedance inversion. Lead Edge 28:772-781

Syrek-Moryc C (2007) Złoże gazu ziemnego Cierpisz ważnym argumentem $\mathrm{w}$ problematyce przyszłych prac poszukiwawczych $\mathrm{w}$ cienkowarstwowych utworach miocenu zapadliska przedkarpackiego i związanych z nim potencjalnych zasobów gazu ziemnego. Nafta-Gaz 2:95-99

Tary JB, Herrera RH, Han J, van der Baan M (2014) Spectral estimation-what is new? What is next? Rev Geophys 2014:723-749

Wiggins R, Kenny GS, McClure CD (1983) A method for determining and displaying the shear-velocity reflectivities of a geologic formation. European patent application 0113944

Yang M (2003) Monochromatic AVO: an indicator that sees through wave interference. In: 73rd annual international meeting SEG, Expanded Abstracts, pp 201-208

Yushun D, Zhaoquan P, Lingbang Z, Mingbo B (2011) Carbonate reservoir and gas-bearing property detection using sweetness. In: SEG annual meeting

Zhang R, Castagna JP (2011) Thin-layer reflectivity inversion using basis pursuit decomposition. Geophysics 76:R147-R158

Zoeppritz K (1919) Erdbebenwellen VIII B, Uber Reflexion und durchgang seismischer wellen duch unstetigkeitsflachen. Gottinger Nachr 1:66-84 